\title{
Controlled Democracy and Political Opposition in Pakistan: A Case Study of Musharraf Era
}

\author{
Dr. Zahoor Ahmed \\ Head of Political Science Department, Govt Islamia College Faisalabad, Pakistan \\ Email: zahoor707@gmail.com \\ Dr. Manzoor Khan Afridi \\ Head of Department of Politics and International Relations \\ International Islamic University Islamabad, Pakistan \\ Email:manzoor_s01@yahoo.com
}

\section{Doi:10.5901/mjss.2014.v5n14p560}

\begin{abstract}
The paper analysez the state of democracy, process of democratization and challenges to the government in Pervez Musharraf regime. It was a time when Musharraf introduced some new phenomena and reforms to the politcal set up of Pakistan. Some were appreciated in and outside of the country but others were bitterly criticized. Musharraf implemented National Security Council (NSC) to check over parliament. It had been observed that all important issues had been dominated by the military establishment. Military establishment adopted forced methology to attain results which were contradictory to democratic norms and values. Aim of the paper here is to discuss that why Musharraf introduced something new and were considered undemocratic? How political forces challenged his government and international pressure was applied? Methodology used in this research is descriptive-analytical, as to describe the events and then analyze them with arguments. It is concuded in the paper that Pakistani public rejected Musharraf and his allies in 2008 general elections, by bringing a civil democratic political structure in country.
\end{abstract}

Keywords: Musharraf, Democracy, PCO, NRO, Benazir Bhutto

\section{Introduction}

Pakistan grew out with the political frustration since independence. Its political history is filled with military and civilian regimes. Musharraf regime should be divided into two parts e.g. military regime and civilian regime. From 1999 to 2002, Musharraf enjoyed complete authority alone whereas from 2002 to 2008, he had to accommodate the civilian government. Double standard political regime had been observed during Musharraf era. National and international political observers calculated his regime in the context of War on Terrorism. Washington had compromised democracy in Pakistan because of concrete steps taken by Musharraf on War on Terrorism. On political front, he did almost all those things what his predecessors Ayub Khan and Zia-ul-Haq did to extend his power. At the initial stage, Musharraf did not touch judiciary and had taken oath under 1973 constitution as Chief Executive. In return, he was given political concession by the judiciary for next three years in keeping with promise to hold election before expiry of 3 years. Superior Judiciary had continued its practice according to 1973 constitution. Issue of Provincial constitution Order (PCO) was raised in January 2000, when the petitions against Musharraf were conceptionally acknowledged. Now Musharraf Administration decided to approach those judges whose voices were favorable. Finally, judiciary was again hijacked and had entertained Musharraf with oath ceremony under PCO, introduced by military regime. It was not new development in the political spectrum of Pakistan. Later on, Musharraf implemented accountability, introduced pro-Musharraf political party, friendly opposition and National Security Council to dominate parliament. With these developments, Musharraf sidelined moderate and secular minded political parties and put forward MMA in parliament for securing maximum benefits under the shadow of War on Terrorism. Musharraf launched military operations against Taliban in northern areas and banned religious Jihadi organizations in Punjab and Karachi. These forceful military operations had promoted extremism and severely damaged the entire society. The observers stated that Musharraf support on War on Terrorism had shaken Pakistan's political and economic infrastructure. The foreign investors packed luggage and local investors preferred to move across the state. No doubt, Washington financially assisted Pakistan but the losses, faced by the 
Pakistani society was extremely tough.

With these circumstances, Musharraf scheduled new election plan in 2008. This time, the situation was not comfortable for him. He was clearly told that all political parties will take part in election. The political elicits, Benazir Bhutto and Mian Nawaz Sharif signed Charter of Democracy with new political ambitions and plans. It was observed that lesson had been learnt from history and now planned political struggle against Musharraf regime. In next, Judiciary was not pleased with Musharraf so that the favorable circumstances were not board. It was the understood reality that Musharraf' King Party will not receive good results in coming election. In the presence of Nawaz Sharif and Benazir Bhutto, Muslim League (Q) was at the lowest ebb. Apart from other social problems, Lal Masjid (Red Mosque) episode and Bughti killing had lemmatized the scope of Musharraf and Muslim League (Q). The following events misplaced the political scene. Inflation, unemployment, extremist forces, distorted security circumstances, energy crisis and sinking economic conditions had paralyzed the Pakistani society. Situation touched dangerous level when Benazir Bhutto was killed. It is recorded statements that Musharraf government was asked many times to provide "fool-prove" security but requests were not entertained. With these socio-political circumstances, election shades were scheduled with delay of few days. Now the expected election results questioned Musharraf' regime and raised new challenges before new government. The political elites approached poling of reconciliation' in the light of charter of democracy and coalition government was formed. Muslim League (N) shared government with Pakistan people's party with new expectations and hopes.

In meanwhile, both leadership signed Boharban Declaration to actualize the spirit of charter of democracy it is observed that Prime Minister, Yousaf Raza Gillani dismantled the imposed restrictions over the judges of the superior judiciary but now challenge to functionalize or restore Chief Justice, Iftikhar $\mathrm{Ch}$. and others honorable judges. This issue became obstacle between PPP and Muslim League (N) which finally compelled Mian Nawaz Sharif to withdraw from ministries. It happened as it was expected because unnatural political alliance faded democracy. So that struggle was started by Muslim League $(\mathrm{N})$ others political parties, lawyers and civil society members to restore Ch. Muhammad Iftikhar. Finally, the long march achieved destiny in Gujranwala when Mian Nawaz Sharif was assured that judiciary, with letter and spirit, will be restored. Question before PPP was not concerned regarding restoration of Iftikhar Muhammad Ch and other judges but actual story was revolving around NRO Deal, which had been challenged already in Supreme Court. It was already argued that NRO Deal was not ethically acknowledged within civil society. Swiss Case and money laundering case were also filed against Asif Ali Zardari. Mr. Asif Ali Zardari was interested to maintain Justice Dogar status, favorable to Musharraf. It has been observed that institutional interests were not followed and democratic values were manipulated by the civilian government. With this commitment and luck of challenges, the new elected government opened tussle with judiciary.

It should be clearly mentioned that Pakistan Armed Forces decided to keep away from internal political involvement. Chief of Army Staff, General Pervaiz Ashfaq Kayany clearly passed out orders to vacate all civil administration posts and only to focus military professionalism. It was good movement licenses military officers' involvement within civil administration evoked had image of Pakistani force within common man. Secondly, the military officers were on board with civilian government to fight against the militant forces. Now the principal function of civilian and military leadership was to stabilize state on internal and external fronts.

\section{Charter of Democracy: Lesson from History}

Charter of democracy is a signed political accord between Benazir Bhutto and Nawaz Sharif, on May 142006 in London, the third political consensus among the politicians, was expressed as democratic march towards institutionalization process in Pakistan. It is called third consensus democratic document after Objective Resolution 1949 and 1973 Constitution. According to the Charter of Democracy, Constitutional Amendments introduced by General Musharraf will be no more practiced. Such as;

- State mechanism, placed by General Musharraf, including the National Security Council will be abolished.

- Pakistan Armed Forces and National Security Council organs will be placed under civilian political control.

- Firm civilian government control and scrutiny over Pakistan's intelligence agencies.

In letter of spirit, the objective of Character of Democracy was to keep military away from interference within the political set up. It was argued that the civilian leadership interpreted 'Charter of Democracy' as document to avoid institutional interference. A welcome and encouraging step of political parties was to consolidate democracy. In Pakistan, it has been termed as, "It is hardly an exaggeration to say that it is one of the most important, and despite its understated prose, the most stirring thing to come out of Pakistan's confused milieu in a long time". It was called Magna Carter of 
Pakistan, opened new window for democracy. National political consensus was staged out in result of great efforts of the political leaderships, reflected notion of matured political reconciliation. It was observed that the political parties articulated a process of democratic transitions (Charter of Democracy, 2006).

The Parliamentary Committee on Constitutional Reforms (PCCR) introduced following recommendations to the People's Government for establishment of democratic institutions.

- "The Federal Government, through the Ministry of Defense, shall provide equal opportunities for recruitment to all Provinces, including FATA, so as to ensure uniformity in the recruitment policy of the Armed Forces."

- "The Government may specify a period of 90 days for the Tribunal to complete the trial in the Representation of Peoples Act, 1976 and that a consequential penalty on the parties be imposed for any delay."

- "Article 247: The Government should take immediate steps to implement the reforms announced by the President in respect of FATA, particularly, about major changes in the Frontier Crimes Regulation and providing opportunities to the National Political Parties to organize their activities in that area. The Government may also associate other parties who are stakeholders in the ongoing consultations regarding administration of Tribal Areas."

- Article 9: The Government should make appropriate laws regarding "security of person".

- "Article 192: The Appointing Authority should bear in mind that the appointment of judges to the Islamabad High Court should include Judges from all the provinces and the Islamabad Capital Territory."

- "The Government may ensure that the Federal Secretary Finance is not appointed as the Auditor General of Pakistan."

- "Concurrent Legislative List (Fourth Schedule): The Government should constitute an Implementation Commission for the devolution process and transition as a consequence of abolition of the Concurrent List."

- "Article 161(1): The Government may expeditiously provide infrastructure for the utilization of water in the Provinces, where it does not exist."

- "Item 11 of Federal Legislative List: The Committee recommends that in view of a major devolution of powers and responsibilities to the Provinces in the constitutional reforms package, it is imperative that the extent of and modalities for distribution of work between the Federal Public Service Commissions, Provincial Public Service Commissions and the respective services be reworked and the services reorganized as to ensure provincial autonomy and good governance. It is also recommended that adequate indigenization of the services should also take place as part of this reform."

- "The Committee recommended that the Islamabad High Court be conferred original civil jurisdiction in cases of the value of Rupees five million or above or such other amount as may be determined by an Act of Parliament."

- "To promote harmony, stability and goodwill between the Baloch, Pakhtun and all the communities in the Province of Baluchistan, the Committee recommended that equity be maintained in all spheres of life till the structural problems involved are resolved by mutual dialogue and consensus. It is further recommended:

- That the Federal Government will keep in mind the traditions being followed in the appointments of Constitutional offices in the Province.

- That the Provincial Government will strictly follow and enforce the zonal employment scheme;

- That the allocation of development funds in the Province will be done in a manner where in regional disparities and backwardness is given priority."

Musharraf's proclamation of imposing emergency, as to justify in terms of, destroyed security circumstances of state approached a serious threat to life and property of the Pakistani citizens. Further, judiciary role was projected as negative, which claimed to be "working at cross purposes with the executive and legislature in the fight against terrorism and extremism thereby weakening the Government and the nation's resolve and diluting the efficacy of its actions to control this menace." According to proclamation, "the situation required "emergent and extraordinary measures." On day of emergency, Pervaiz Musharraf enforced PCO as Army Chief for Supreme Court. The judiciary was forced to take oath under PCO, which restricted judiciary to challenge orders of Pervaiz Musharraf as under any authority. In fact, fundamental rights, given by 1973 Constitution, were suspended by Pervaiz Musharraf, as regarding about freedom from unlawful arrest and detention, freedom of movement, assembly, association, and speech. Now the question before Musharraf was to ask judiciary for taking oath under PCO in search for legitimacy. In this matter, situation was not favorable to Musharraf likely to be past. Musharraf approached Chief Justice, Iftikhar Muhammad Choudhry for resolving conflict. This time, Chief Justice's response was not positive and had refused simply to follow instructions, passed by G.H.Q. Again independence of judiciary was at stake. Finally Musharraf efforts come true as Justice of Supreme Court 
Dogar finally took oath in the light of PCO from Musharraf. Along with other six judges of Supreme Court judges adopted line of action, as defined by Justice Dogar. Dogar court was not accepted by the civil society and the lawyers associations throughout country. The 'Lawyer Movement', either literate or illiterate, whether young or old without any discrimination, had participated to restore the independence of the judiciary. It was a civil march towards respect for judiciary, headed by Chief Justice Iftikhar Muhammad Ch. himself. The movement was welcomed throughout country and appeared as a serious challenging situation for Mr. Musharraf. It was observed that Musharraf had taken wrong perception regarding consequences. In meanwhile, 12 May incident shocked everyone, a tragic event happened when few lawyers were fired in Karachi. The day was called Black Day by the judiciary. Mr. Iftikhar Ch. had to come back from Karachi due to insecure environment in Karachi. Musharraf Administration was trying at best level to curb the movement but each step had to revert like Newton law.

\section{Anti-Musharraf Struggle}

Now the political parties channelized a platform for launching Anti-Musharraf campaign. The political leadership especially Muslim League (N) and PPP launched anti-Musharraf political rallies throughout country. Now it was the best time to compel Musharraf for bargaining. The local organizations of the political parties mobilized common man against Musharraf. A full-fledged political crisis was emerged in the context of judicial crisis. The restoration of Chief Justice was considered the credibility of the political system. Secretary of State, Condoleezza Rice telephonically informed that Supreme Court would not be subservient to military rule, and could derail President's Musharraf's political plans. In the meanwhile, Musharraf had to face another political defeat when the exiled leadership was permitted to return Pakistan. It was widen stoppage of the Musharraf government to deal this new political development. In September, the Islamabad police arrested political workers including the leadership of Muslim League (N) and PPP. A statement from U.S. Embassy called the development, "extremely disturbing and confusing" and Secretary, Rice called the arrests "troubling". It has been observation, delivered by Itzar Ahan "U.S. Government not seeming to care about Musharraf's crack down on the Supreme Court and making no mention of the issue in various briefings."

On $6^{\text {th }}$ October 2007, President Musharraf was elected again as President and secured approximately $57 \%$ votes, out of 1,170 members Electorate College. Other members of the Electorate College had preferred either remained to out of this process. Musharraf had set his mind that he would leave uniform because of the prevailing circumstances, did not suit to him. It was evident reality for Musharraf that as civilian President, he had to face more institutional challenges because the political understanding was developed among the political parties rather than military. It was a known fact that military influential institutional force was main contributing factor to sustain Musharraf's regime. The political parties showed reaction against Musharraf's re-election and simply called violation of 1973 Constitution. Again Musharraf had to face serious setback as the Supreme Court of Pakistan ruled that it will accept all those petitions, registered against Musharraf's re-election. Question about legitimacy of the President Musharraf's re-election became question mark. In this new scenario, Musharraf thought that in case of leaving uniform, he might be fail to face against those writs, challenging to Mr. Musharraf's legitimacy as re-elected president. As matter of Mr. Musharraf's idea of leaving uniform became question mark. Musharraf's political friends suggested that he must be given assurance regarding his confirmation as President; uniform issue remained to be pending. Finally the situation cleared as 'New Supreme Court', under PCO given green signal to Mr. Musharraf. All filed writ petitions were cancelled and Musharraf was given path to hold Presidency again. In second thought, Musharraf planned to leave army chief status.

\section{Politics of Controlled Democracy}

It is not now a secret like to be past that Musharraf had shown intention on various occasions to build a political understanding with Benazir Bhutto. In reality, Musharraf wanted to have mutual understanding with PPP but conditionally. In the beginning, Musharraf-Benazir talks failed because the former wanted PPP to be in next government set up but only to exclude latter from the political scene. The cases will not be examined again against both Benazir Bhutto and Asif Zardari would keep themselves from politics. Asif Ali Zardari will be released from jail and he had to leave country. The dialogue failed and Musharraf had to touch with second choice, called Muslim League (Q). For the formation of government in center, Musharraf arranged a political alliance between Muslim League (Q) and MQM and finally few members of PPP were snatched with heavy price. In this way a government set up was established. Now the circumstances for Mr. Musharraf were not as favorable as in past (Hussain, 2007). Except many factors, one important factor that Musharraf was politically weak, but still in doing extra-ordinary. Now again a 'deal package' was introduced to patch up between Musharraf and Benazir Bhutto. For this, the west was also interested to arrange a deal between both 
even though the common friends within state and a crossed were doing efforts for deal. This time, Benazir position was comparatively better. Recently, a historic document was drafted between Benazir and Nawaz Sharif, called Charter of Democracy. So that Benazir was in better position to deal Musharraf. She went forward and signed a deal with Musharraf. Musharraf wanted to keep himself in the presidency and Benazir wanted to get rid of all those cases, registered against her and Mr. Asif Ali Zardari. Benazir knew that her political survival can be matured in case of closing of all cases (Lamb, 2007). These were the field cases in courts and NAB since 1988 to 1999, during different tenures. Benazir acknowledged that Musharraf's survival was close to die but his breath had come alive only with her support. So as matter of fact, Benazir had to compromise with Musharraf. Negotiations regarding power sharing formula were the staged between both. Musharraf was conscious of his role in next political set up and Benazir Bhutto was worried to be elected as third time Prime Minister. Washington argued that it should be considered better when the role of Mr. Musharraf will be sustained if the moderate political forces will be synthesized in new political set up. It was understood phenomenon that Musharraf and Benazir wanted to keep Islamic militancy away from political spectrum. Benazir had to face threats from the Islamic militant organizations occasionally.

In this spectrum, Musharraf had to face three serious suicidal attacks, fortunately alive. So the moderate political understanding, towards national and international matters, can be evolved in case of political alliance between both. Benazir and Musharraf met in Dubai and agreed to draft finally. The said deal, called National Reconciliation Ordinance (NRO) Deal. Musharraf issued National Reconciliation Ordinance (NRO) to facilitate all those political leaders who had to face litigation related to maladministration and corruption charges and their cases were still pending. The tenure was fixed from 1988 to 1998. In this ordinance, all cases were declared null and void, simply provided clean sheet to maximum number of politicians. Everyone had received benefits from NRO. The political intellectuals and civil society members argued that said deal damaged Benazir Bhutto because she violated Charter of Democracy (Reuters, 2007).

Ch. Shujat Hussain stated that Musharraf offered NRO deal to Benazir Bhutto only to disunite the opposition. Second, it is a known fact that Charter of Democracy was considered a real threat to political rule of Muslim League (Q). Finally, Washington Administration welcomed a compromise understanding between Musharraf and Benazir Bhutto. It is a fact that in these changing circumstances; Musharraf Administration was interested to accept Benazir but neither to face Benazir-Nawaz Sharif alliance. Even then within Peoples Party, one group argued that Benazir did same thing as Pakistan People Party (Patriot Group), led by Mr. Aftab Sheer Pao, Faisal Saleh Hayat and others. Second group argued that Benazir Bhutto and Asif Ali Zardari were observing political distortion in the presence of these registered cases. So that Benazir had to deal NRO finally to give up all these cases. Benazir Bhutto stated that NRO should be considered a political deal for smooth transition of democracy from authoritarian regime (White \& Ali, 2007). In these circumstances, it was said that the military establishment played vital role for promoting understanding between Benazir and Pervaiz Musharraf. It was simple power sharing settlement between military and civilian leadership again.

\section{US and Others' Reaction about Musharraf's Policies}

Pakistan's political circumstances were in chaos and assembled with uncertain matters. The issues were not properly addressed. The institutions were treated on basis of personal gaining power instead of strengthening them. Apart from this, the growing Islamic militancy had paralyzed the security system within state. It was constant threat to Pakistan's image as peaceful sate internally and externally. The judicial crisis disturbed respects for institutions (Admiral, 2007). In these circumstances, it was growing political rumor that Martial Law will be imposed by Musharraf through an emergency proclamation. When Condoleezza Rice was asked about the possibility of Martial Law regime in future, she said "it was quite obvious that Washington would not be supportive of extra-constitutional means". In addition, she expressed possible reaction of Washington likely to be, "Pakistan needs to be preparing for a hold free and fair elections" (Jay \& Peter, 2007). The next day, the Commander of U.S. Central Command, Adam William Fallon met with Musharraf in Islamabad and warned against declaring state of emergency and that would "Pakistan-US Relationship at risk". On the other hand, it was another statement from Washington that in case of imposing emergency, Musharraf government will be secured due to increasing tendency of Islamic militancy in Pakistan. Some pro-Musharraf friends in Washington argued that Musharraf should be given chance because as 'sole commitment' against war on terrorism of Islamabad with Washington. Musharraf did efforts to convince that security threats from terrorism and extremism had paralyzed state, so that he should be given open choice. Few political observers argued that due to deal between Musharraf-Benazir, should be considered a green signal for Musharraf, whereas, Washington Administration argued that it supported moderate forces in Pakistan as matter of reconciliation in positive direction (Speech, 2007).

As far as issue of imposing Emergency in Pakistan, by Musharraf is concerned, Washington will not support it because election will be ultimate future way for democratic institutionalization process. Finally, Musharraf imposed 
emergency and it was suspension of fundamental laws again. Musharraf advocated emergency by arguing that it is the need of time and he had to take up this action due to threats from the extremist forces, facing to Pakistan continuously. This way of thinking, Musharraf paralyzed the state's institutions. The mass movement was launched against emergency. Throughout country, massive public protests were organized by different organizations (Paul, 2007).

Musharraf government used state's power to curb the mass movement, cracked down and finally events reflected as extreme form of dictatorship. Washington expressed 'grave concern' at the crackdown, calling such "extreme and unreasonable measures," contradictory to the goal of a fully democratic Pakistan. Musharraf amended 1952 Army Act, allowed military trials of civilians, calling human rights group and potentially providing a retroactive sanctioning of 'disappearances' traced to country's security services and criticized by the Supreme Court. Washington called the emergency of Pakistan as serious setback regarding democratization process. International community showed serious consequences (MOFA, 2007). Pakistan's neighbors were not pleased with Musharraf's act. India stated that internal developments in Pakistan are not hopeful for smooth working relationships. In the difficult times that Pakistan is passing through (Commonwealth: 2007, MOFA: 2007). In response to prevailing circumstances as to what called unwarranted criticism and excessive reactions from abroad. Commonwealth Ministerial Action Group suspended Pakistan's membership. It issued, "a condemnation of the abrogation of the Pakistani Constitution and threatened Pakistan with suspension from the Commonwealth unless Musharraf repeals the emergency provisions, retires from the army, releases all political detainees, and removes curbs on media freedom by November 22". Commonwealth Ministerial Action Group (CMAG) issued a "condemnation of the abrogation of the Pakistani Constitution and threatened Pakistan with suspension from the commonwealth unless Musharraf repeals the emergency provisions, retires from the army releases all political detainees, and removes curbs on media freedom by November 22. Islamabad expressed "deep disappointment and regret" to the CMAG statement, saying it reflected "ignorance to the ground realities". On November 22, the CMAG made good on its suspension threat pending restoration of democracy and rule of law there. Islamabad expressed "deep regrets" at the "unreasonable and unjustified" decision, saying it "does not take into account the objective conditions prevailing in Pakistan." International human rights groups were vociferous in their criticism: New York-based Human Rights Watch decried the "coup against Pakistan's civil society" and demanded that Pakistan immediately return to constitutional rule and end its crackdown on the judiciary, media, human rights activists, and political opponents. London based Amnesty International warned that the "wholesale abrogation of fundamental human rights protections" represented a "blatant breach of international law" and it also demanded the restoration of human rights and justice (Amnesty International, 2007). The Pakistani public appeared overwhelmingly opposed to Musharraf's coup, but street protests were relatively modest in scale (due in part to police crackdowns and blockades) (Sam: 2007, David: 2007, Simon: 2007, Indian EAM: 2007). The Pakistani media were largely unanimously in their criticism of what was widely seen to be a bald-faced attempt by Musharraf to maintain his own power in the face of increasing pressures (Washington Post, 2007). Many leading U.S. press outlets urged "the Bush Administration to end its reliance on Musharraf, seeking him as an obstacle both to more effective counterterrorism efforts and to democratization". On December, 15, President Musharraf lifted the state of emergency in what he claimed was a "complete restoration of the constitution" (BBC, 2007). In a speech to the Pakistan nation, he again asserted that the emergency was declared as a last resort "against my own will" in order to defeat a "conspiracy" to "derail the democratic process. Musharraf also took credit for laying "the foundation of real democracy." (Agency France Press, 2007). Skeptics saw little evidence that the lifting of the emergency would lead to meaningful change, given what they see as repressive media curbs and a stacked judiciary. One senior Pakistani analyst visualized Musharraf's move a "public relations exercise" (Human Rights Watch, 2007).

\section{Bhutto's Return to Pakistan}

In 2007, Benazir decided to return Pakistan for participating in next election. It is a known fact that Benazir Bhutto was threatened by the Jihadi Islamist organization. Tahreek-e-Taliban Pakistan was the organization which initiated plan to kill Benazir Bhutto. Even though Benazir expressed reservations against her security during exile and demanded tight security from Washington and Musharraf. On many occasions Musharraf was requested by Benazir to provide foolproof security. It is a fact that Benazir criticized Taliban Organizations in Pakistan and watched out them a serious threat to Pakistan. These events were in background as she reached Karachi. Benazir was warmly welcome by the supported in Karachi was encouraging indicator for the PPP. It was assumed that after NRO Deal with Musharraf, Benazir had to face isolation but neither was it happened like perception. Benazir had to face first suicide attack after just and few hours she reached Karachi. More than hundred people were killed in bomb blast, Benazir was saved. The situation was alarming for Benazir in political campaign. She was instructed to be careful during election campaign. On December $27^{\text {th }}, 2007$, Benazir was assassinated, returning from Liaqat Abad, Rawalpindi, attended political campaign. It was fully planned 
suicide attack; she was successfully targeted by the killers (The NEWS: 2007, Agency France Press: 2007).

Washington stated, "Cowardly attack", strongly condemned by the west media. Throughout Pakistan, massive public protests were started, shut down of services and anticipation of violence. Serious riots occurred in rural Sind Karachi. First report, issued by government was to confirm Benazir's assassination due to vehicle sunroof, hit her head. After few minutes, the report was issued that Benazir was target killing through proper shoot firing by a young man, close to her vehicle. In time of shooting fire at Benazir, a blast occurred near her damaged her vehicle badly and killed many others who surrounded her. As she was shifted to hospital for recovery, the roads were cleaned and washed, removed all ground evidences. During investigation, a senior police officer argued that everything was washed as he received orders from high authorities. In way of thinking a proper planning was staged to kill Benazir, indirectly to remove from political scene. It was a serious political setback for Pakistan which lost a major political figure (Washington Post, 2007). Before killing, Benazir herself argued that she is facing serious reservations regarding security. She did not have that kind of required security measures as accordingly she was promised. She approached the Americans and Musharraf to provide security for avoiding complicated situation but promise was not fulfilled. Pakistan People's Party (PPP) demanded that United Nations Organization (UNO) should be given mandate to investigate Benazir Bhutto case. However, the political chapter of Benazir Bhutto was finished. In meanwhile, Musharraf's reconstituted Supreme Court acknowledged his reelection as President and provided path to leave uniform. Musharraf had no option except to now appear as civilian president. Secretary of state, Condoleezza Rice called this act 'Musharraf acknowledged situation and his resignation as Army Chief called first step". In further, she said, "the most stabilizing thing for Pakistan will be to have of free and fair elections." (Bhutto: 2007, Sharif: 2007). Musharraf said that he had planned to conduct election in January but, not assured to inform exact date regarding uplifting emergency. It was obvious that Benazir Bhutto simply refused to do things according to deal with Musharraf. Even though, she launched a long march and convinced others to finally sabotage Musharraf.

It has been observed that Pervaiz Musharraf was interested in controlled democracy. So that democracy will be mixed with blend of dictatorship. Such sort of financial and political interests of the army for interfering in the political process of Pakistan are to be listed respectively.

"The army has such a large monetary stake in the country that it will never allow a populist civilian government to interfere with the status quo. A civilian government may be permitted to continue only so far as it does not interfere with the financial interests of the army. Only a revolution may bring about a change in this state of affairs. Any civilian government brought into office by normal sedate democratic channels will neither have the strength, nor will it be permitted, to pursue a political or economic policy, which the military does not regard as conductive to its interests."(Khan, 1989).

By keeping internal and external political scenario, Musharraf allowed Benazir and Nawaz to take part in Pakistan's politics. It's a major fact that Lawyer's Movement extremely disappointed Musharraf because all political parties channelized their resources to compel him to restore original democratic spirit. No doubt Benazir-Musharraf were approached on deal but it lost its importance as emergency was imposed. Before assassination, Benazir publically warned Musharraf that imposition of emergency will be serious violation of fundamental rights and her political party will be on road for long March against him. As Musharraf imposed emergency, Benazir said "Musharraf is over-launched long march towards Islamabad". So finally Benazir Bhutto's reaction was expressed as threat to internal security. Against this, Benazir Bhutto was home arrested (Dawn: 2007, Jay:2008). Benazir Bhutto asked international and national media and crossed political leaders to stop dictatorial acts and compelled him to patch way to democratic forces. Mian Nawaz Sharif strongly condemned Musharraf's act regarding Benazir home arrest. He said that Benazir's changing stance from Musharraf should be considered a winning situation for democratic institutions because now dictator is alone. Further, he said that he welcomed the swift change of Benazir Bhutto who was interested to provide concession to Musharraf after deal. Qazi Hussain Ahmad, leader of Jamat-i-Islami welcomed Benazir's stance about Musharraf. In this scenario, it was difficult for Musharraf to provide maximum security to Benazir Bhutto. Now situation was difficult for Musharraf to face new circumstances after Benazir's changing attitude. Benazir ruled out any further possibilities of concession in politics for Mr. Musharraf. She said that she had no interest to conclude power sharing formula with Musharraf. For Muslim League (Q), it was confrontation movement because as allay to Musharraf, the party was not acceptable for public in election campaign. Possibilities of negotiation with Benazir were at the lowest ebb and now public agitation against Musharraf crossed peak level (Associated Press, 2008). 


\section{Conclusion}

Since Pakistan's independence, 'Democracy' still has not been out of excuse from legitimacy. Pakistan has seen democracy in different terms and conditions. During Ayub Khan and Zia-ul-Haq regimes, democracy had been introduced according to requirement. In Musharraf regime, controlled democracy phenomenon had been flourished and parliament was kept under control of the military establishment. It is undemocratic tendency that Mr. Shaukat Aziz, having no political background and no political party affiliation had been nominated Prime Minister of Pakistan. Mr. Shaukat Aziz was a 'banker' and was in good book of the military establishment. Respectively, the parliamentarian party, Muslim League (Q) did not bother to argue before the military establishment. Musharraf implemented National Security Council (NSC) to check over parliament. It had been observed that all important issues had been dominated by the military establishment. Lal Masjid (Red Mosque) and Bughti Killing were the decisions, influence by the military establishment. Pervaiz Musharraf ignored the dialogue process in both cases and the state had to face security challenges. The international media projected both cases against Pakistan. As to take perception, it will be rightly said that military establishment adopted forced methology to attain results which were contradictory to democratic norms and values. With passage of time, the political scenario was changed and political power was transferred to new civilian government. Challenges before new parliament were tremendous and were fully exhausted. Issue of terrorism and Baluchistan crisis were at distortion level. Continuous suicide bombing and massive killing in Karachi had faded that economic prosperity of the state. It was surprised that new blend of government (PPP+ Muslim League $(\mathrm{N})$ was unique political alliance in the shadow of charter of democracy and policy of 'Reconciliation'. Expectations from this unique political alliance were high but complications were still present. On issue of restoration of Judiciary, the alliance was expired and Muslim League $(\mathrm{N})$ followed the option of Long-March to restore judiciary, resulted positive. Now PPP government had to face judiciary tussle and political separation from Muslim League (N) PPP formed political alliance with ANP, Muslim League (Q), Jamiat-eUlma Islam (F) Fazul-ur-Rehman group and Muthadia-Qaumi Movement (MQM- Altaf Group).

With this new political set up, the civilian government introduced political agenda. One change was staged, caused restoration of 1973 constitution. PPP government introduced $18^{\text {th }}$ Amendment which changed the identical features of the system of government. Prime Minister Office was empowered as compared to president office. The $18^{\text {th }}$ Amendment redesigned the functions of the federal government and provincial governments. Since independence, the civilian governments were fighting for democracy and institutionalization process. 2008 election had revamped Musharraf legacy and new government with unique political alliance had taken up the political matters. 'Charter of Democracy' was a positive development which ensured principal of co-operation and co-ordination among the political forces. It was expected that lesson from history will bring responsibility to hold high offices. It was hoped that the coalition government will readdress the central-province relationship.

\section{References}

Admiral (2007, November 6). U.S. Warned Musharraf Against Emergency Declaration. CNN.com

Bhutto, B. (2007, November 14). Musharraf's Electoral Farce. Washington Post

Bhutto, B. (2007, November 7). Musharraf's Martial Plan. New York Times

Editorial. (2007, December 31). PPP's New Leader. Dawn

Editorial (2007, November 11). The General Must Go. Washington Post

Hussain, I. (2007, August 29). Deal-ing a Bad Hand. Daily Times

Jane, P. (2007, November 11). Bhutto's Persona Raises Distrust, As Well As Hope. New York Times

Jay, S. \& Peter, W. (2007, November 23). Pakistan Alerted U.S. It Planned Emergency Rule. Wall Street Journal,

Jay, S. (2008, January 2). Pakistan's Zardari Poses a Quandary for U.S. Wall Street Journal

Khan, M. (1989, April 3-5). 1973 Constitution - The Founding of the Federation, an unpublished paper read at a seminar: "The Heritage of Prime Minister Bhutto," in Karachi. note 10

Lamb, C. (2007, November 18). Threat to Strip Benazir Bhutto of Amnesty. Sunday Times

Paul, A. (2007, December 19). Pakistan's Government Threatens Media. Associated Press

Rhode, D. (2007, November 9). Anger at Decree Runs Deeps in Pakistanis. New York Times

Sam, D. (2007, November 3). World Leaders Condemn State of Emergency in Pakistan. Associated Press

Sharif, N. (2007, November 17). Pakistan's One-Man Calamity. Washington Post

Simon, G. (2007, November 4). Pakistan's Media Slams Musharraf's 'Second Coup. Reuters Unofficial speech transcript at [http://www.indybay.org/newsitems/2007/11/05/18458318.php]

Wallace, B. (2007, December 3). Skepticism Tinges Support for Bhutto. Los Angeles Times

White, G. and Ali, I. (2007, November 2). U.S. Warns Musharraf Not to Use Martial Law. Washington Post 
(2007, December 13). Analysts Doubt Change After Pakistan Emergency Ends. Agency France Press

(2007, November 9). Benazir Terms Pledge 'Vague, Insufficient'. The NEWS

(2007, November 13). Bhutto to Musharraf: It's Time to Quit. Agence France Presse

(2007, November 14). Bhutto's own niece has called the political posturing "sheer pantomime" (Fatima Bhutto, "Aunt Benazir's False Promises," Los Angeles Times

(2006, May 14). Charter of Democracy Original Text. www.charter/democracy/Pakistan.com

(2008, January 1). Former PM Now Leads Pakistan Opposition. Associated Press

(2007, November 4). Human Rights Watch. http://hrw.org/english/docs/2007/11/04/pakist17241.htm

(2007, November 3). Indian External Affairs Ministry Press Release

(2007, November 17). Musharraf, In Interview, Holds Firm on Crackdown. Washington Post.

(2007, November 13). Pakistan's Bhutto Building Opposition Alliance. Agence France Presse

(2007, December 16). Text of Pakistan President's Speech on Lifting Emergency. BBC Monitoring South Asia

(2007, November 17). U.S. Trying to Revive Musharraf-Bhutto Deal. Reuters

http://web.amnesty.org/library/print/ENGASA330412007

http://www.mofa.gov.pk/Press_Releases/2007/Nov/PR_271_07.htm

http://www.mofa.gov.pk/Press_Releases/2007/Nov/PR_277_07.htm

http://www.thecommonwealth.org/news/172238/121107 cmag.htm 